\title{
Remigiusz J. Kijak, Zofia Szarota, Starość. Między diagnozq a działaniem, Centrum Rozwoju Zasobów Ludzkich, Warszawa 2013, ss. 122
}

Recenzowana książka, jak sam jej tytuł wskazuje, obejmuje zakresem treści problematykę gerontologiczną i nieco wbrew tytułowi nie ma charakteru poradnika metodycznego. Autorzy skoncentrowali się głównie na opisie procesów starzenia się w Polsce, specyfice starzenia się jednostkowego, a przede wszystkim w perspektywie społecznej. Praca zawiera także postulaty do działań w skali makro (np. w rozdziale II Wsparcie społeczne i polityka społeczna wobec późnej dorosłości i starości) i do pracy indywidualnej (np. rozdział III Specyfika pracy socjalnej z seniorami - wybrane aspekty). Jest wartościową publikacją, poszerzającą rodzime zbiory biblioteki gerontologicznej.

Pierwsze trzy rozdziały publikacji są autorstwa Zofii Szaroty. Książkę otwiera część poświęcona demograficznym i społecznym aspektom starzenia się społeczeństwa. Autorka rozpoczyna od analizy struktury najstarszej grupy wiekowej w Polsce, powołuje się na dane międzynarodowe, prognozując stały wzrost udziału tejże generacji w populacji Polaków; odnosi się również do narastających problemów i wyzwań naszego kraju: starzenia się społeczeństwa, społecznego podziału pracy, niskiego przyrostu naturalnego, sytuacji materialnej, zdrowotnej czy pełnionych ról społecznych seniorów. Drugi rozdział zawiera części, których wspólnym mianownikiem jest wsparcie społeczne. Głównym odniesieniem do działań wpierających rozwój w późnej dorosłości jest w niniejszej pracy polityka społeczna, silver economy oraz organizacja życia społeczno-kulturalnego. Specyfika pracy socjalnej $z$ seniorami - wybrane aspekty to tytuł trzeciego rozdziału. Poza opisem klasycznych metod pracy socjalnej z uwzględnieniem specyfiki pracy na rzecz osoby starszej i z osobą starszą, na uwagę zasługują rozważania na temat profesjonalnych kadr gerontologicznych z interesującymi postulatami „edukacji dla starości”.

Autorem kolejnych trzech rozdziałów jest Remigiusz J. Kijak. Dwie części autorstwa tego badacza odnoszą się do wybranych obszarów życia w starości. Pierwsza $z$ nich dotyczy seksualności, a druga zagrożenia, jakim jest przemoc wobec osób starszych. Rozdział kończący książkę podejmuje tema- 
tykę postaw wobec osób starszych oraz poczucia jakości życia samych seniorów. Część poświęcona seksualności osób w podeszłym wieku oparta jest na wielu ustaleniach dokonanych w wyniku badań, przeważnie przeprowadzonych przez uczonych z zagranicy, gdzie analizy naukowe tej sfery życia ludzi starych są bogatsze niż w Polsce (choć dziwić akurat może brak nawiązań do publikacji np. Lwa-Starowicza). Autor odwołuje się także do własnych ustaleń, co należy uznać za wartość tego opracowania. W tekście znaleźć można także odniesienie do zagadnień związanych z życiem intymnym osób niepełnosprawnych. Piąty rozdział książki podnosi kwestie przemocy wobec osób starszych; jest to typowe kompendium wiedzy na ten temat, oparte na rodzimych i zagranicznych badaniach z tego zakresu. Kończący całą książkę rozdział składa się $z$ dwóch części. Pierwsza traktuje o stylach starzenia się i postawach ludzi starych wobec starości oraz uwarunkowaniach tychże procesów i zachowań. Druga cześć opisuje postawy wobec starości widziane z perspektywy innych generacji.

Publikacja jest z pewnością materiałem źródłowym cennym dla szerokiego grona odbiorców: pracowników socjalnych, opiekunów osób starszych, studentów nauk społecznych i humanistycznych, a także samych seniorów i tych wszystkich, którzy w praktyce i teorii zajmują się na co dzień seniorami. Treści książki są niewątpliwie aktualne, oparte na dziełach autorstwa wielu wybitnych polskich i zagranicznych badaczy procesów starzenia się. Pewne wątpliwości budzi struktura pracy (brak wyraźnego klucza) i wybór treści. Dlaczego wyeksponowano życie intymne ludzi starych, a nie np. życie religijne czy aktywność fizyczna? Dlaczego spośród zagrożeń wybrano przemoc, a nie inne, dużo bardziej powszechne problemy, jak np. ubóstwo. Jest to jednak prawo autorów, a wybór jest z pewnością konsekwencją ich zainteresowań naukowych, co dowodzą, rzetelnie opracowując w swojej publikacji wybrane obszary życia w starości. 